\title{
PENDAMPINGAN PROSES PEMBELAJARAN LURING SISWA MADRASAH IBTIDAIYAH MELALUI MODEL PEMBELAJARAN SCIENTIFIC LEARNING DESA KARANGSARI BANYUWANGI PADA ERA COVID-19
}

\author{
Ahmad Izza Muttaqin ${ }^{1)}$, Anis Fauzi ${ }^{2)}$, Al Muftiyah ${ }^{3)}$, Tamara Bunga Velia ${ }^{4)}$ \\ Institut Agama Islam (IAI) Ibrahimy Genteng Banyuwangi, Indonesia \\ e-mail: $\underline{\text { izza@iaiibrahimy.ac.id }}$
}

\begin{abstract}
Learning is a process of interaction between students, educators and learning resources and evaluation to achieve the learning process. Community service is realized in the form of mentoring student learning processes from home. Offline learning is a form of learning that is not at all connected to the internet. Offline learning is the opposite of darling learning. Meanwhile, Scientific learning is an approach used in learning with a focus on the use of scientific methods in the learning process. The subject is a student of MI Darul Ulum class $V$ and parents of students. Aiming to overcome the problem of student learning at home during the darling Covid-19 period. Some of the program activities undertaken are as follows: a) Offline Learning Process at Home b) Learning Assistance with Scientific Learning Approach.
\end{abstract}

KEYWORDS: Offline Learning, Scientific Learning

\begin{tabular}{|c|c|c|}
\hline Accepted: & Reviewed: & Published: \\
December 27 2020 & January 102021 & February 15 2021 \\
\hline
\end{tabular}

\section{PENDAHULUAN}

Pendidikan merupakan bagian terpenting dari masyarakat. Karena pendidikan adalah salah satu faktor yang sangat menentukan dan berpengaruh terhadap perubahan sosial (Rahman, 2018). Pendidikan adalah wadah manusia untuk mengembangkan ilmu pengetahuan dan teknologi serta berbagai aspek lainnya. Pendidikan di era globalisasi juga memberikan dampak yang signifikan bagi pengembangan pola piker masyarakat di dalam membaca situasi dan kondisi yang terjadi di suatu negara. Pendidikan merupakan dasar terjadi suatu perubahan. Melalui pendidikan, masyarakat dapat mengetahui cara yang tepat untuk menyesuaikan cara berpikir untuk menghadapi tantangan dunia yang semakin kompleks dan membutuhkan daya saing yang tinggi. (As' adi \& Muttaqin, 2019) Sistem pendidikan di indonesia pada pasca pandemi era covid- 
13 | Pendampingan Proses Pembelajaran Luring Siswa Madrasah Ibtidaiyah Melalui Model Pembelajaran Scientific Learning Desa Karangsari Banyuwangi Pada Era Covid-19

19 mengalami perubahan pada tanggal 16 Maret 2020 yang mengakibatkan peserta didik harus melaksanakan kegiatan belajar berbasis online (daring), baik jenjang sekolah TK, SD/MI, SMP, SMA ataupun jenjang sekolah perguruan tinggi (kuliah) tidak bisa dilakukan secara langsung dikarenakan dapat menyebabkan dampak terhadap penyebaran penyakit Covid-19. Salah satu dampak yang paling terlihat selama proses pembelajaran adalah keefektivan proses belajar siswa di rumah pada jenjang sekolah MI Darul Ulum Desa Karangsari. Pasalnya, tidak semua siswa sekolah MI Darul Ulum Desa Karangsari dapat mengikuti kegiatan pembelajaran darling (dalam jaringan) atau online seperti siswa-siswa sekolah yang berada di kota. Karena tidak semua siswa MI Darul Ulum Desa Karangsari memiliki Handphone seluler dan memiliki jaringan internet yang baik, yang mengakibatkan siswa MI Darul Ulum Desa Karangsari tidak dapat mengikuti pembelajaran darling atau online secara efektif. Oleh sebab itu, penelitian melakukan sebuah pendampingan pembelajaran luring (luar jaringan) atau konvensional (tatap muka) kepada siswa sekolah MI Darul Ulum di rumah sesuai dengan protokol kesehatan serta mengaplikasikan model pembelajaran scientific learning pada pembelajaran tematik.

Menurut Hosnan (2014:34) menjelaskan pendekatan scientific learning adalah proses pembelajaran yang dirancang sedemikian rupa agar peserta didik secara aktif mengontruk konsep, hukum atau prinsip melalui tahapan-tahapan mengamati (untuk mengidentifikasi atau menemukan masalah), merumuskan masalah, mengajukan atau merumuskan hipotesis, mengumpulkan data dengan berbagai teknik, menganalisis data, menarik kesimpulan dan mengomunikasikan konsep, hukum atau prinsip yang ditemukan. Tujuan pendekatan saintifik dalam pembelajaran di antaranya yaitu untuk meningkatkan kemampuan berpikir siswa, membentuk kemampuan dalam menyelesaikan masalah secara sistematik, menciptakan kondisi pembelajaran agar siswa merasa bahwa belajar merupakan suatu kebutuhan, melatih siswa dalam mengemukakan ide-ide, meningkatkan hasil belajar siswa, dan mengembangkan karakter siswa. De Vito (dalam Putra, 2013:55) juga menjelaskan bahwa pendekatan saintifik adalah pendekatan pembelajaran yang memungkinkan terbudayakannya kecakapan berpikir ilmiah sekaligus terkembangkannya sense of inquiry dan kemampuan berpikir kreatif siswa. Selanjutnya, Partin (2009:401) juga menjelaskan bahwa pendekatan saintifik merupakan dasar-dasar dari sebuah riset yang memungkinkan siswa mengumpulkan data dengan objektif untuk memecahkan permasalahan.

Berdasarkan pendapat di atas, sehingga dapat disimpulkan bahwa model 
pembelajaran scientific learning agar siswa mampu merumuskan masalah dengan banyak menanya bukan hanya menyelesaikan masalah dengan cara memberikan jawaban dan dapat mengembangkan atau menumbuhkan karakter pada siswa. Pendekatan saintifik tidak hanya dapat diterapkan pada bidang keilmuan sains terapan (eksakta) saja, melainkan pada semua bidang keilmuan. Selain itu, hal yang terpenting dalam pendekatan saintifik adalah dapat membentuk siswa mempunyai domain sikap, keterampilan, dan pengetahuan yang seimbang dan utuh sesuai dengan tuntutan pendidikan abad 21.

Pengabdian kepada masyarakat merupakan salah satu komponen kegiatan pendampingan proses pembelajaran luring (luar jaringan). Pembelajaran luring (luar jaringan) tersebut tidak dilakukan seperti proses pembelajaran di dalam kelas. Akan tetapi, proses pembelajaran dilakukan dengan konvensional (tatap muka) kepada siswa sekolah MI Darul Ulum di rumah secara langsung yang tetap menggunakan peraturan sesuai prokotol kesehatan supaya dapat membantu orang tua siswa yang kurang maksimal dalam pendampingan belajar anak di rumah pada masa era pandemic covid-19, yang disebabkan faktor orang tua sibuk bekerja sebagai petani.

Upaya perbaikan terhadap proses pembelajaran darling atau online kepada siswa di rumah, penelitian melakukan sebuah program pendampingan pembelajaran luring (luar jaringan) atau konvensional (tatap muka) kepada siswa sekolah MI Darul Ulum di rumah dengan menggunakan modus pembelajaran langsung (direct instructional). Pembelajaran langsung adalah pembelajaran yang mengembangkan pengetahuan, kemampuan berpikir, dan keterampilan menggunakan pengetahuan siswa melalui interaksi langsung dengan sumber belajar. Dalam pembelajaran langsung siswa melakukan kegiatan mengamati, menanya, mengumpulkan informasi, menalar, dan mengkomunikasikan. Pembelajaran langsung menghasilkan pengetahuan dan keterampilan langsung, yang disebut dengan dampak pembelajaran (instructional effect).

Permasalahan yang lain dihadapi terutama untuk membantu terhadap keluhan orang tua siswa terkait dengan pembelajaran mandiri di rumah, keluhan anak mengenai serapan materi dan keluhan terhadap ketidakmerataan akses teknologi dalam pembelajaran darling atau online. Kegiatan pendampingan pembelajaran luring (luar jaringan) kepada siswa sekolah MI Darul Ulum kelas $\mathrm{V}$ dapat terlaksanakan dengan baik yaitu $75 \%$ walaupun tidak secara optimal seperti pembelajarn yang di lakukan di dalam kelas.

Dari penerapan di atas, peneliti tertarik untuk melakukan program pendampingan pembelajaran luring (luar jaringan) atau langsung pada siswa MI 
15 | Pendampingan Proses Pembelajaran Luring Siswa Madrasah Ibtidaiyah Melalui Model Pembelajaran Scientific Learning Desa Karangsari Banyuwangi Pada Era Covid-19

Darul Ulum di rumah serta mengaplikasikan model pembelajaran scientific learning pada masa pandemi covid-19 di Desa Karangsari Dusun Truko Kabupaten Banyuwangi Provinsi Jawa Timur.

\section{METODE PELAKSANAAN}

Program ini dijalankan selama 45 hari dan dilaksanakannya kegiatan pendampingan belajar siswa di rumah dengan seminggu 3 kali dalam pertemuan tatap muka secara langsung, dalam pelaksanaan program KKN Tematik "proses pendampingan pembelajaran luring (luar jaringan) siswa sekolah MI Darul Ulum melalui model pembelajaran scientific learning" di Desa Karangsari Kabupaten Banyuwangi pasca pandemi Covid-19.

Adapun metode dalam pendampingan ini sebagai berikut:

1. Tahap Persiapan

a. Survei atau observasi lokasi untuk pelaksanaan kegiatan.

b. Penyusun rencana jadwal untuk pelaksanaan kegiatan.

c. Penyusunan materi untuk pelaksanaan kegiatan.

d. Evaluasi permasalahan berupa penentuan solusi untuk pelaksanaan kegiatan.

2. Tahap Pendampingan

Pendampingan dilaksanakan pada masa era pandemi Covid-19 dalam bentuk pendampingan pembelajaran luring (luar jaringan) atau pembelajaran langsung kepada siswa di rumah melalui model pembelajaran scientific learning. Tujuan penelitian untuk membantu orang tua siswa yang kurang maksimal dalam pendampingan pembelajaran anak secara mandiri dan mengembangkan terhadap pemahaman materi pelajaran.

3. Tahap Evaluasi

Evaluasi dilakukan untuk melihat tingkat keberhasilan kegiatan mulai dari awal, proses hingga capaian hasil kegiatan. Pengumpulan data yang dihasilkan selanjutnya dianalisis dan ditarik kesimpulan apakah program dapat dilanjutkan atau dihentikan sehingga program memiliki tujuan yang jelas, memiliki alternatif pemecahan masalah yang dihadapi dan diharapkan berjalan dengan baik.

\section{HASIL DAN PEMBAHASAN}

Kegiatan program kuliah kerja nyata $(\mathrm{KKN})$ yang dilaksanakan di rumah siswa pada pasca pandemi Covid-19 yang bertempat di Desa Karangsari yang terletak di Dusun Truko. Program ini dilaksanakan dalam proses pendampingan 
pembelajaran luring (luar jaringan) kepada siswa sekolah MI Darul Ulum melalui model pembelajaran scientific learning.
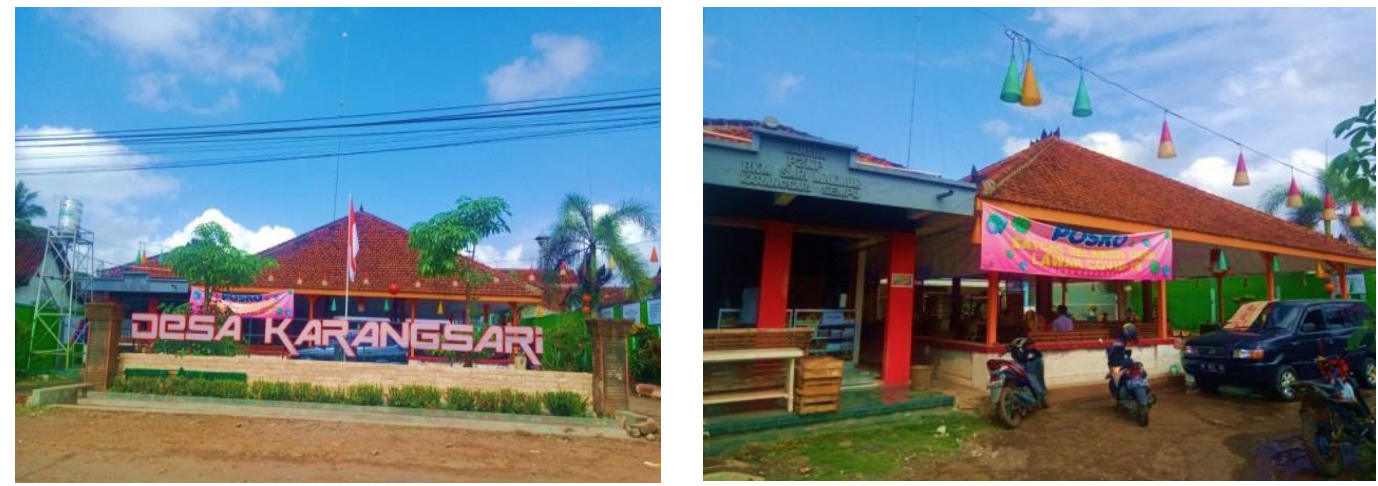

Gambar 1. Kantor Desa Karangsari

\section{Observasi atau Wawancara Orang Tua Siswa}

Sebelum peneliti melaksanakan program pendampingan pembelajaran luring (luar jaringan) kepada siswa sekolah MI Darul Ulum melalui penerapan model pembelajaran scientific learning. Peneliti melakukan observasi wawancara kepada orang tua siswa terhadap proses pembelajaran di rumah selama masa pandemi covid-19.

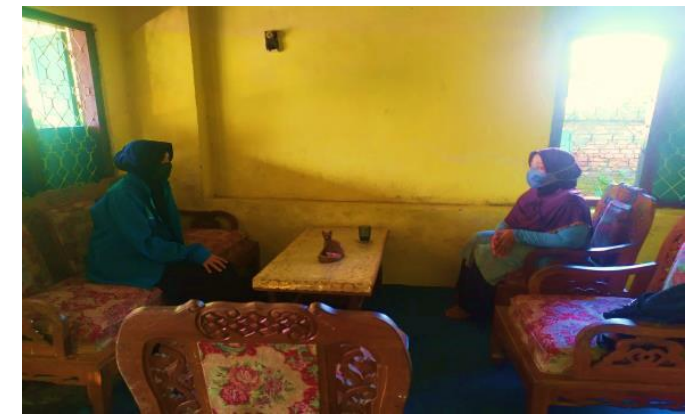

\section{Gambar 2. Wawancara kepada orang tua siswa}

Hasil wawancara dengan orang tua siswa terhadap proses pembelajaran darling kepada siswa di rumah pada masa pandemi covid-19 adalah adanya hambatan permasalahan, sebagai berikut:

1. Keluhan orang tua wali terkait dengan pembelajaran mandiri pada anak.

2. Tidak semua orang tua wali mampu berperan maksimal dalam mendampingi proses belajar anak.

3. Kurangnya anak mengenai serapan materi dalam belajar di rumah. 
17 | Pendampingan Proses Pembelajaran Luring Siswa Madrasah Ibtidaiyah Melalui Model Pembelajaran Scientific Learning Desa Karangsari Banyuwangi Pada Era Covid-19

4. Keluhan terhadap ketidakmerataan akses anak atau orang tua terhadap teknologi dalam pembelajaran.

Berikut tanggapan Orang tua siswa dan siswa selama proses pembelajaran darling pada masa pandemi era covid-19, sebagai berikut:

1. Tanggapan orang tua siswa

Orang tua beranggapan bahwa pada situasi pandemi covid-19 sebagai orang tua yang bekerja sebagai petani, ketika pulang kerja sudah pasti lelah sehingga tidak dapat mendampingi anaknya belajar. Adapula orang tua dalam mendampingi anak belajar di rumah meski terlihat menyenangkan bukanlah sesuatu yang mudah khususnya bagi sang ibu karena kurang kreatif dan tidak bisa menahan kesabarannya.

2. Tanggapan siswa

Ketika masa pembelajaran dilakukan di rumah siswa diharuskan menunggu materi dan latihan soal yang akan di kirim oleh guru melalui pembelajaran darling, sehingga dapat menimbulkan kebosanan terhadap siswa karena setiap hari akan mendapatkan tugas tanpa bantuan guru.

\section{Pembelajaran Luring (Luar Jaringan)}

Pembelajaran di sekolah biasanya dilakukan di dalam kelas. Namun, pada masa pandemi Covid-19 pemerintah mengharuskan guru dan siswa belajar dari rumah. Sejak saat itu, mengakibatkan siswa harus melaksanakan kegiatan belajar di rumah melalui sarana darling. Akan tetapi, tidak semua peserta didik mampu untuk mengakses pembelajaran darling secara optimal. Pembelajaran darling kini dapat digantikan dengan pembelajaran secara luring (luar jaringan) yang sesuai dengan mematuhi protokol kesehatan.

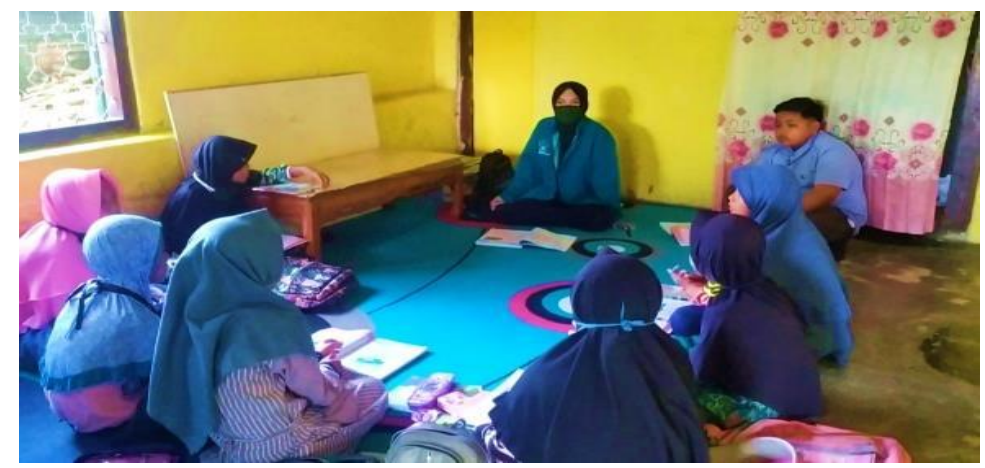

Gambar 3. Pelaksanaan Pembelajaran Luring Siswa MI Darul Ulum 
Berikut langkah-langkah pembelajaran luring (luar jaringan), sebagai berikut:

a. Persiapan

1) Menyusun rencana pelaksanaan pembelajaran luring (luar jaringan).

2) Memiliki alamat rumah siswa yang akan dikunjungi untuk pembeljaran luring (luar jaringan).

3) Mempersiapkan materi atau bahan ajar yang akan diajarkan.

b. Pelaksanaan

1) Menyampaikan materi kepada siswa yang dilakukan dari rumah selama masa pandemi covid-19.

2) Mengembangkan materi dalam bentuk konkrit atau riil.

3) Memberikan tugas atau latihan soal kepada siswa.

c. Evaluasi

1) Memeriksa hasil tugas atau latihan soal yang sudah dikerjakan oleh siswa.

2) Memberikan umpan balik terhadap hasil tugas, sehingga siswa termotivasi belajar.

\section{Model Pendekatan Scientific Learning}

Pada masa pandemi covid-19, penelitian menggunakan penerapan model pendekatan scientifik learning. Tujuan pendekatan saintifik dalam pembelajaran diantaranya yaitu untuk meningkatkan kemampuan berpikir siswa, membentuk kemampuan dalam menyelesaikan masalah secara sistematik, menciptakan kondisi pembelajaran agar siswa merasa bahwa belajar merupakan suatu kebutuhan, melatih siswa dalam mengemukakan ide-ide, meningkatkan hasil belajar siswa, dan mengembangkan karakter pada siswa. Pendekatan scientific learning yang berisikan proses pembelajaran yang didesain agar siswa mengalami belajar secara aktif. Pendekatan scientific learning merupakan bagian dari pendekatan pedagogis pada pelaksanaan pembelajaran. Proses pembelajaran yang mengimplementasikan pendekatanm scientific learning akan menyentuh tiga ranah, yaitu; sikap (afektif), pengetahuan (kognitif), dan keterampilan (psikomotor). Dengan proses pembelajaran scientifik learning maka diharapkan hasil belajar yang produktif, kreatiif, inovatif, dan afektif melalui penguatan sikap, keterampilan, dan pengetahuan yang terintegrasi.

Menurut Hosnan (2014:34) menjelaskan pendekatan scientific learning adalah proses pembelajaran yang dirancang sedemikian rupa agar peserta 
19 | Pendampingan Proses Pembelajaran Luring Siswa Madrasah Ibtidaiyah Melalui Model Pembelajaran Scientific Learning Desa Karangsari Banyuwangi Pada Era Covid-19

didik secara aktif mengontruk konsep, hukum atau prinsip melalui tahapantahapan mengamati (untuk mengidentifikasi atau menemukan masalah), merumuskan masalah, mengajukan atau merumuskan hipotesis, mengumpulkan data dengan berbagai teknik, menganalisis data, menarik kesimpulan dan mengomunikasikan konsep, hukum atau prinsip yang ditemukan. Sedangkan

Menurut (Kemendikbud,2013), menjelaskan pendekatan scientific learning adalah "proses" mencapai hasil akhir tertentu, bukan justru tertuju pada hasil akhir yang telah diperoleh. Informasi yang diperoleh dapat berasal dari mana saja, kapan saja, dan tidak tergantung pada informasi searah dari guru. Oleh karena itu, kondisi pembelajaran yang diharapkan tercipta diarahkan untuk mendorong siswa untuk mencari berbagai sumber informasi, bukan diberi tahu. Kondisi pembelajaran seperti ini diharapkan agar siswa dapat merumuskan masalah (dengan banyak menanya), bukan hanya menyelesaikan masalah dengan menjawab saja.

Berikut langkah-langkah penerapan modul pendekatan scientific learning, sebagai berikut:

\begin{tabular}{|c|c|c|c|}
\hline No & $\begin{array}{l}\text { Langkah } \\
\text { Pembelajaran }\end{array}$ & $\begin{array}{l}\text { Deskripsi } \\
\text { Kegiatan } \\
\text { Kompetensi }\end{array}$ & $\begin{array}{l}\text { Kompetensi } \\
\text { Dikembangkan }\end{array}$ \\
\hline 1. & $\begin{array}{l}\text { Mengamati } \\
\text { (observing) }\end{array}$ & $\begin{array}{l}\text { Mengamati dengan } \\
\text { indra (membaca, } \\
\text { mendengar, melihat, } \\
\text { menyimak, man } \\
\text { menonton, dan } \\
\text { sebagainya) dengan } \\
\text { atau tanpa alat. }\end{array}$ & $\begin{array}{lr}\text { Perhatian pada } & \text { waktu } \\
\text { mengamati } & \text { suatu } \\
\text { objek/membaca } & \text { suatu } \\
\text { tulisan/ mendengar } & \text { suatu } \\
\text { penjelasan, catatan } & \text { yang } \\
\text { dibuat tentang yang } \\
\text { diamati, kesabaran, waktu } \\
\text { (on task) yang digunakan } \\
\text { untuk mengamati. } \\
\end{array}$ \\
\hline 2. & $\begin{array}{l}\text { Menanya } \\
\text { (questioning) }\end{array}$ & $\begin{array}{l}\text { Membuat dan } \\
\text { mengajukan } \\
\text { pertanyaan, tanya } \\
\text { jawab, berdiskusi } \\
\text { tentang informasi } \\
\text { yang belum } \\
\text { dipahami, informasi } \\
\text { tambahan yang }\end{array}$ & $\begin{array}{l}\text { Jenis, kualitas, dan jumlah } \\
\text { pertanyaan yang diajukan } \\
\text { siswa (pertanyaan faktual, } \\
\text { konseptual, prosedural, dan } \\
\text { hipotetik). }\end{array}$ \\
\hline
\end{tabular}


Ahmad Izza Muttaqin, Anis Fauzi, Al Muftiyah \& Tamara Bunga Velia| 20

\begin{tabular}{|c|c|c|c|}
\hline & & $\begin{array}{lr}\text { ingin } & \text { diketahui, } \\
\text { atau } & \text { sebagai } \\
\text { klarifikasi. } & \\
\end{array}$ & \\
\hline 3. & $\begin{array}{l}\text { Mengumpulkan } \\
\text { informasi/ } \\
\text { mencoba } \\
\text { (experimenting) }\end{array}$ & $\begin{array}{l}\text { Mengeksplorasi, } \\
\text { mencoba, } \\
\text { berdiskusi, } \\
\text { mendemonstrasikan } \\
\text {, meniru bentuk/ } \\
\text { gerak, melakukan } \\
\text { eksperimen, } \\
\text { membaca sumber } \\
\text { lain selain buku } \\
\text { teks, } \\
\text { mengumpulkan data } \\
\text { dari nara sumber } \\
\text { melalui angket, } \\
\text { wawancara, dan } \\
\text { memodifikasi/ } \\
\text { menambahi/ } \\
\text { mengembangkan. }\end{array}$ & \begin{tabular}{lr}
\multicolumn{3}{l}{ Jumlah dan kualitas sumber } \\
yang dikaji/ digunakan, \\
kelengkapan informasi, \\
validitas informasi yang \\
dikumpulkan, & dan \\
instrumen/alat & yang \\
digunakan & untuk \\
mengumpulkan data.
\end{tabular} \\
\hline 4. & $\begin{array}{l}\text { Menalar/ } \\
\text { Mengasosiasi } \\
\text { (associating) }\end{array}$ & $\begin{array}{l}\text { Mengolah informasi } \\
\text { yang sudah } \\
\text { dikumpulkan, } \\
\text { menganalisis data } \\
\text { dalam bentuk } \\
\text { membuat kategori, } \\
\text { mengasosiasi atau } \\
\text { menghubungkan } \\
\text { fenomena/ } \\
\text { informasi yang } \\
\text { terkait dalam } \\
\text { rangka menemukan } \\
\text { suatu pola, dan } \\
\text { menyimpulkan. }\end{array}$ & $\begin{array}{l}\text { Mengembangkan } \\
\text { interpretasi, argumentasi } \\
\text { dan kesimpulan mengenai } \\
\text { keterkaitan informasi dari } \\
\text { dua fakta/konsep, } \\
\text { interpretasi argumentasi } \\
\text { dan kesimpulan mengenai } \\
\text { keterkaitan lebih dari dua } \\
\text { fakta/konsep/teori, } \\
\text { menyintesis dan } \\
\text { argumentasi kerta } \\
\text { kesimpulan keterkaitan } \\
\text { antar berbagai jenis } \\
\text { fakta/konsep/teori/pendapat } \\
\text {; mengembangkan } \\
\text { interpretasi, struktur baru, } \\
\text { argumentasi, yan } \\
\text { kesimpulan dan } \\
\text { menunjukkan hubungan } \\
\text { fakta/konsep/teori dari dua } \\
\text { sumber atau lebih yang } \\
\text { tidak bertentangan; } \\
\text { mengembangkan }\end{array}$ \\
\hline
\end{tabular}


21 | Pendampingan Proses Pembelajaran Luring Siswa Madrasah Ibtidaiyah Melalui Model Pembelajaran Scientific Learning Desa Karangsari Banyuwangi Pada Era Covid-19

\begin{tabular}{|c|c|c|c|}
\hline & & & $\begin{array}{lr}\text { interpretasi, struktur } & \text { baru, } \\
\text { argumentasi } & \text {,dan } \\
\text { kesimpulan } & \text { dari } \\
\text { konsep/teori/pendapat yang } \\
\text { berbeda dari berbagai jenis } \\
\text { sumber. }\end{array}$ \\
\hline 5. & $\begin{array}{l}\text { Mengomunikasika } \\
\mathrm{n} \text { (communicating) }\end{array}$ & $\begin{array}{lr}\text { Menyajikan } & \text { laporan } \\
\text { dalam } & \text { bentuk } \\
\text { bagan, } & \text { diagram, } \\
\text { atau } & \text { grafik; } \\
\text { menyusun } & \text { laporan } \\
\text { tertulis; } & \text { dan } \\
\text { menyajikan } & \text { laporan } \\
\text { meliputi roses, } & \text { proses } \\
\text { hasil, } & \text { dan } \\
\text { kesimpulan } & \text { secara } \\
\text { lisan. } & \end{array}$ & $\begin{array}{l}\text { Menyajikan hasil kajian } \\
\text { (dari mengamati sampai } \\
\text { menalar) dalam bentuk } \\
\text { tulisan, grafis, media } \\
\text { elektronik, multi media dan } \\
\text { lain-lain. }\end{array}$ \\
\hline
\end{tabular}

Melihat paparan pada tabel di atas, rasanya kurang rinci apabila tidak dijelaskan lebih lanjut dengan struktur yang spesifik. Akan tetapi, perlu diketahui bahwa langkah-langkah tersebut tidak selalu dilalui secara berurutan, terlebih pada pembelajaran tematik, di mana pembelajarannya menggunakan tema sebagai pemersatu. Sementara setiap mata pelajaran memiliki karakteristik keilmuan antara yang satu dengan lainnya tidak sama. Oleh karena itu, agar pembelajaran bermakna perlu diberikan contoh-contoh agar dapat lebih memperjelas penyajian pembelajaran dengan pendekatan saintifik. Untuk lebih jelasnya dapat dilihat pada uraian berikut:

1. Mengamati

Menurut Samatowa (2011:94), kegiatan mengamati merupakan keterampilan dasar yang harus dimiliki oleh setiap siswa dalam melakukan penyelidikan ilmiah (the basic of all scientific inquiry is observation). Mengamati mengutamakan proses pembelajaran (meaningfull learning). Kegiatan mengamati seperti menyajikan media obyek secara nyata, siswa senang dan tertantang, dan mudah pelaksanaannya. Kegiatan mengamati sangat bermanfaat bagi pemenuhan rasa ingin tahu siswa. Sehingga proses pembelajaran memiliki kebermaknaan yang tinggi. Dengan mengamati siswa menemukan fakta bahwa ada hubungan antara objek yang dianalisis dengan materi pembelajaran yang digunaka. 


\section{Menanya}

Menurut Hanafiah dan Cucu Suhana (2010:74), menjelaskan menanya adalah proses pembelajaran yang dilakukan siswa yang diawali dengan proses bertanya. Proses bertanya yang dilakukan siswa sebenarnya merupakan proses berpikir yang dilakukan siswa dalam rangka memecahkan masalah dalam kehidupannya. Kegiatan menanya mempunya fungsi yang sangat penting dalam pembelajaran scientifik learning. Adapun fungsi dari kegiatan menanya antara lain sebagai berikut:

a. Membangkitkan rasa ingin tahu, minat, dan perhatian siswa tentang suatu tema atau topik pembelajaran tertentu.

b. Mendorong dan menginspirasi siswa untuk aktif belajar, serta mengembangkan pertanyaan dari dan untuk dirinya sendiri.

c. Mendiagnosis kesulitan belajar siswa terhadap apa yang ditanyakannya sekaligus menyampaikan rancangan untuk mencari solusinya.

d. Menstrukturkan tugas-tugas dan memberikan kesempatan kepada siswa untuk menunjukkan sikap, pengatahuan, dan keterampilannya atas substansi pembelajaran yang diberikan.

e. Membangkitkan keterampilan siswa berbicara dalam mengajukan pertanyaan secara logis, sistematis, dan menggunakan bahasa yang baik dan benar.

f. Mendorong partisipasi siswa dalam berdiskusi, berargumen, mengembangkan kemampuan berpikir, dan menarik simpulan.

g. Membangun sikap keterbukaan untuk saling memberi dan menerima pendapat atau gagasan, memperkaya kosa kata, serta mengembangkan toleransi sosial dalam hidup berkelompok.

h. Membiasakan siswa berpikir spontan dan cepat, serta sigap dalam merespon persoalan yang tiba-tiba muncul.

i. Melatih kesantunan dalam berbicara dan membangkitkan kemampuan berempati satu sama lain.

3. Menalar

Istilah menalar dalam konteks pembelajaran pada kurikulum 2013 dengan pendekatan saintifik banyak merujuk pada teori belajar asosiasi atau pembelajaran asosiatif. Istilah asosiasi dalam pembelajaran merujuk pada kemampuan mengelompokkan beragam ide dan mengasosiasikan beragam peristiwa untuk kemudian memasukannya menjadi penggalan memori. Teori menalar ini sangat efektif menjadi landasan menanamkan sikap ilmiah dan 
23 | Pendampingan Proses Pembelajaran Luring Siswa Madrasah Ibtidaiyah Melalui Model Pembelajaran Scientific Learning Desa Karangsari Banyuwangi Pada Era Covid-19

motivasi pada siswa berkenaan dengan nilai-nilai instrinsik dari pembelajaran partisipatif. Dengan cara ini siswa akan melakukan peniruan terhadap apa yang nyata dalam observasinya.

Aplikasi dalam pengembangan aktivitas pembelajaran untuk meningkatkan daya menalar siswa dapat dilakukan dengan cara berikut ini:

a. Menyusun bahan pembelajaran dalam bentuk siap pakai sesuai dengan tuntutan kurikulum.

b. Tidak banyak menerapkan metode ceramah dengan memberi instruksi singkat tapi jelas disertai dengan contoh-contoh, baik dilakukan sendiri maupun dengan cara simulasi.

c. Bahan pembelajaran disusun secara berjenjang atau hierarkis, dimulai dari yang sederhana (persyaratan rendah) sampai pada yang kompleks (persyaratan tinggi).

d. Kegiatan pembelajaran berorientasi pada hasil yang dapat diukur dan diamati.

e. Setiap kesalahan harus segera dikoreksi atau diperbaiki.

f. Perlu dilakukan pengulangan dan latihan agar perilaku yang diinginkan dapat menjadi kebiasaan atau pelaziman.

g. Evaluasi atau penilaian didasari atas perilaku yang nyata atau otentik.

h. Mencatat semua kemajuan siswa untuk kemungkinan memberikan tindakan pembelajaran perbaikan.

4. Mencoba

Untuk memperoleh hasil belajar yang nyata, siswa harus mencoba atau melakukan percobaan, terutama untuk materi atau substansi yang sesuai. Pada mata pelajaran IPA misalnya, siswa harus memahami konsep-konsep IPA dan kaitannya dengan kehidupan sehari-hari. Siswa pun harus memiliki keterampilan proses untuk mengembangkan pengetahuan tentang alam sekitar, serta mampu menggunakan metode ilmiah dan bersikap ilmiah untuk memecahkan masalah-masalah yang dihadapinya sehari-hari. Aplikasi mencoba dimaksudkan untuk mengembangkan berbagai ranah tujuan belajar, yaitu sikap, pengetahuan, dan keterampilan. Kegiatan pembelajaran dengan mencoba dilakukan melalui tiga tahap, yaitu: persiapan, pelaksanaan, dan tindak lanjut.

Agar pelaksanaan percobaan dapat berjalan lancar maka: (1) guru hendaknya merumuskan tujuan eksperimen yanga akan dilaksanakan siswa; (2) guru bersama siswa mempersiapkan perlengkapan yang dipergunakan; (3) 
perlu memperhitungkan tempat dan waktu; (4) guru menyediakan kertas kerja untuk pengarahan kegiatan siswa; (5) guru membicarakan masalah yang akan dijadikan percobaan; (6) membagi kertas kerja kepada siswa; (7) siswa melaksanakan percobaan dengan bimbingan guru; dan (8) guru mengumpulkan hasil kerja siswa dan mengevaluasinya, bila dianggap perlu didiskusikan secara klasikal.

\section{Mengkomunikasikan}

Pada kegiatan akhir diharapkan siswa dapat mengkomunikasikan hasil pekerjaan yang telah disusun baik secara bersama-sama atau secara individu dari hasil simpulan yang telah dibuat bersama. Kegiatan mengkomunikasikan ini dapat diberikan klarifikasi agar siswa mengetahui secara benar apakah jawaban yang telah dikerjakan sudah benar atau ada yang harus diperbaiki.

Indikator yang tergolong mengkomunikasikan hasil menurut Samatowa (2011:102) antara lain:

a. Menyampaikan dan mengklarifikasikan ide/gagasan dengan lisan maupun tulisan.

b. Membuat catatan hasil observasi dalam percobaan.

c. Menyampikan informasi dalam bentuk grafik, chart, atau tabel.

d. Memilih alat komunikasi yang cocok agar mudah dipahami oleh orang lain.

Berdasarkan hasil wawancara dan pendampingan luring (luar jaringan) kepada siswa kelas V sekolah MI Darul ulum melalui model pembelajaran scientific learning pada masa pandemi covid-19 dapat terlaksanakan dengan baik yaitu $75 \%$ walaupun tidak secara optimal seperti pembelajarn yang di lakukan di dalam kelas. Oleh sebab itu, model pembelajaran scientific learning mampu untuk meningkatkan kemampuan intelektual khususnya kemampuan berfikir pada siswa dan terciptanya kondisi pembelajaran dimana siswa merasa bahwa belajar itu merupakan kebutuhan.

\section{SIMPULAN}

Berdasarkan dari hasil program kegiatan pendampingan luring (luar jaringan) kepada siswa kelas V sekolah MI Darul ulum yang bertempat di Desa Karangsari Dusun Truko dengan penerapan model pembelajaran scientific learning pada masa pandemi covid-19, dapat ditarik kesimpulan bahwa penggunaan model pembelajaran scientific learning pada proses belajar siswa di 
25 | Pendampingan Proses Pembelajaran Luring Siswa Madrasah Ibtidaiyah Melalui Model Pembelajaran Scientific Learning Desa Karangsari Banyuwangi Pada Era Covid-19

rumah pada masa pandemi covid-19 untuk melatih kecakapan, keterampilan terhadap anak, dan pembelajaran anak lebih efektif. Apabila siswa mengikuti pembelajaran dalring di rumah dapat menimbulkan kebosanan dan pengurangan terhadap semangat belajar siswa, karena pembelajaran darling hanya dilakukan dengan pemberian rangkuman materi singkat dan tugas latihan tanpa seorang guru yang menjadikan proses pembelajaran kurang efektif.

\section{DAFTAR RUJUKAN}

As' adi, M., \& Muttaqin, A. I. (2019). PENDAMPINGAN KEGIATAN

KEAGAMAAN DI MASJID AL FALAH DUSUN KRAJAN DESA

SILIRAGUNG KECAMATAN SILIRAGUNG BANYUWANGI. ABDI

KAMI: Jurnal Pengabdian Kepada Masyarakat, 1(2), 105-114.

Daryanto. 2014. Pendekatan Pembelajaran Saintifik Kurikulum 2013. Yogyakarta: Penerbit Gava Media.

Faisol dan Stelly Martha Love. 2018. Pembelajaran Tematik Di Sekolah Dasar. Medan: Penerbit CV. Harapan Cerdas.

Hosnan, M. 2014. Pendekatan Saintifik dan Kontekstual dalam Pembelajaran Abad 21. Bogor: Ghalia Indonesia.

Mashuri, Imam dan Nur Karimah. 2019. Implementasi Pendidikan Karakter Peduli Lingkungan Melalui Program Sekolah Bebas Sampah di SDN 1 Bareng Kabat Banyuwangi. Jurnal JPPM (Jurnal Pengabdian kepada Masyarakat), 1(2). diakses dari https://ejournal.iaiibrahimy.ac.id/openjournal-ibrahimy.html

Musfiqon dan Nurdyansyah. 2015. Pendekatan Pembelajaran Saintifik. (Sidoarjo: Nizamila Learning Center, hlm 37-80.

Rahman, K. (2018). Perkembangan Lembaga Pendidikan Islam di Indonesia. Tarbiyatuna: Kajian Pendidikan Islam, 2(1), 1-14.

Sugiyono. 2017. Metode Penelitian Pendidikan Pendekatan Kuantitatif, Kualitatif dan $R \& D$. Bandung: Penerbit Alfabet. 